\title{
Comparison of the developmental time of Bracon hebetor (Hymenoptera: Braconidae) reared on five different lepidopteran host species and its relationship with digestive enzymes
}

\author{
Dorna SAADAT, Ali R. BANDANI* and MEHDi DASTRANJ \\ Plant Protection Department, University College of Agriculture and Natural Resources, University of Tehran, Karaj, Iran; \\ e-mails: abandani@ut.ac.ir; drn.saadat@gmail.com; m.dastranj@ut.ac.ir
}

Key words. Hymenoptera, Braconidae, Bracon hebetor, lepidopteran hosts, biological parameters, digestive enzymes

\begin{abstract}
Bracon (Habrobracon) hebetor Say is a polyphagous parasitoid of lepidopteran larvae, including those of the family Pyralidae. There are many reports that this parasitoid attacks the larvae of stored product and field crop pests. However, there is little information on the biological parameters of this parasitoid attacking different lepidopteran hosts or the effect of the hosts on the digestive enzymes of the parasitoid. Hence, in the current study the effect of different lepidopteran hosts, Ectomyelois ceratoniae, Plodia interpunctella, Ephestia kuehniella, Helicoverpa armigera and Malacosoma disstria, on the biological parameters and digestive enzymes ( $\alpha$-amylase and proteases) of this parasitoid were investigated. The parasitoid performed better on stored product pests, such as $E$. kuehniella and $P$. interpunctella, than field crop pests, such as H. armigera and M. disstria. For example, in terms of percentage egg hatch, rate of development, off-spring sex ratio and adult dry mass Bracon hebetor did much better when it parasitized stored product insects than field crop insects $(\mathrm{P}<0.05)$. Interestingly, the quality and quantity of the proteases and $\alpha$-amylase of the parasitoid larvae parasitizing stored product and field crop pests differed. The greatest activity of these enzymes was recorded in the gut of those parasitoids that were reared on stored product insects (P. interpunctella and E. kuehniella). It is concluded that stored product insects, which feed on a diet rich in sugar and glycogen, provide physiological conditions that are more suitable for the parasitoid than field crop insects, which feed on diet rich in terpenes and tannins.
\end{abstract}

\section{INTRODUCTION}

Habrobracon (Bracon) hebetor Say (Hym.: Braconidae) is an idiobiont, gregarious, polyphagous ectoparasitoid of many lepidopteran larvae. It attacks the larval stages of several species of Lepidoptera including Ephestia kuehniella, Plodia interpunctella, Ephestia cautella, Corcyra cephalonica, Galleria mellonella, Helicoverpa armigera, Ectomyelois ceratoniae, Amyelois transitella, Tineola bisselliella, Sitotroga cerealella and Malacosoma sp. (Lep.: Lasiocampidae) (Brower et al., 1996; Grieshop et al., 2006; Ghimire \& Philips, 2010; Kishani-Farahani et al., 2012). Thus, it is a good potential biological control agent of storage (Press et al., 1982; Keever et al., 1986) and field pests (Uwais et al., 2006; Imam et al., 2007). This parasitoid prefers to parasitize the final stages of its hosts' larvae (Akinkurolere et al., 2009) and paralyzes them by stinging and injecting them with venom, after which the female lays eggs on the surface of the paralyzed host. Embryonic development under laboratory conditions $\left(27^{\circ} \mathrm{C}\right)$ is reported to be 0.9 days on Corcyra cephalonica, 1.68 on Spodoptera litura, 1.43 on H. armigera, 1.12 on G. mellonella, 1.28 on M. testutalis and 1.63 on E. vittella (Dabhi et al., 2011). Total development time (egg to adult) of $H$. hebetor on different hosts varied from 5.06 days for the male parasitoid on $S$. litura and 31.76 days for the female parasitoid on C. cephalonica (Dabhi et al., 2011). The rapid growth rate (RGR) and short development time of $H$. hebetor contributes to its success, which is dependent on many morpho- logical and physiological adaptations. One morphological adaptation is that its larvae have a blind midgut, which has no direct connection to the hindgut, which prevents larval parasitoids from contaminating the body of their hosts and enables them to rapidly consume and store food. In addition, they store nitrogenous waste as urate granules in their haemocoel, which is a mode of storage excretion (Baker \& Fabrick, 2000). Baker \& Fabrick (2000) studied the changes that occur in the plasma proteins of the host (P. interpunctella) and protein digestion during parasitization by $H$. hebetor. There are no significant changes in the haemolymph proteins of the host $72 \mathrm{~h}$ post-parasitization. In addition, the main endoproteases of the parasitoids are trypsin- and chymotrypsin-like enzymes (serine proteases). Kryukova et al. (2011) report that the parasitoid's venom interacts with the host's immune system. Investigations of the biology of $H$. hebetor parasitizing seven lepidopteran hosts, C. cephalonica, S. cerealella Oliver, Galleria mellonella L., Maruca testulalis Geyer, H. armigera (Hübner) Hardwick, S. litura Fab. and Earias vittella, reveal that $C$. cephalonica and $S$. cerealella are the best hosts for this parasitoid in terms of low male production, fecundity, percentage egg hatch and growth index (Dabhi et al., 2011). In this study the biology of the parasitoid was investigated using five different (except for H. armigera) species of stored product and field crop lepidopteran pests. In addition, the effect of the host on the activities of the digestive enzymes of the parasitoid larvae was studied.

\footnotetext{
* Corresponding author.
} 


\section{MATERIAL AND METHODS}

\section{Insect host rearing}

Carob moths, Ectomyelois ceratoniae Zeller (Lep.: Pyralidae) were originally obtained from infested pomegranate orchards, Indian meal moths, Plodia interpunctella Hübner (Lep.: Pyralidae), from an infested raisin store and Mediterranean flour moths, $E$. kuehniella Zeller (Lep.: Pyralidae) from infested flour in a bakery, cotton bollworm, $H$. armigera Hübner (Lep.: Noctuidae) from infested tomato field and forest tent caterpillars, Malacosoma disstria Hübner (Lep.: Lasiocampidae) from an infested galbanum field (Ferula gummosa Boiss). These species were reared on their respective hosts at $25 \pm 1{ }^{\circ} \mathrm{C}$ (except for carob moth and cotton bollworm, which were reared at $29 \pm 1^{\circ} \mathrm{C}$ and $27 \pm 1^{\circ} \mathrm{C}$, respectively), $65 \pm 5 \% \mathrm{RH}$ and $16 \mathrm{~L}: 8 \mathrm{D} \mathrm{h}$ in a growth chamber.

\section{Parasitoid rearing}

The parasitoid Habrobracon hebetor Say (Hymenoptera: Braconidae) was collected from a raisin store infested with $P$. interpunctella. After rearing a population of the parasitoid on $P$. interpunctella, the parasitoid was transferred and reared for four generations on each of the hosts mentioned above at $27 \pm 1^{\circ} \mathrm{C}, 55$ $\pm 5 \% \mathrm{RH}$ and $16 \mathrm{~L}: 8 \mathrm{D} \mathrm{h}$ in a growth chamber

\section{Developmental time}

In order to determine the developmental time of the parasitoid, fifty mated female parasitoids (48-72 h old parasitoid) were placed with three hundred larvae of each moth species and allowed to parasitize them for $24 \mathrm{~h}$. Then, 40 eggs were selected under stereoscope (all but one of the eggs on a host larva were removed using a needle) on larvae of each of the host species, which were then individually transferred to a Petri dish $(6 \times 0.5$ $\mathrm{cm})$, which was kept in a growth chamber at the $27 \pm 1^{\circ} \mathrm{C}, 55 \pm$ $5 \% \mathrm{RH}$ and $16 \mathrm{~L}: 8 \mathrm{D} \mathrm{h}$ and the embryonic, larval and pupal periods, and development time recorded. In addition, the numbers of males and females were recorded and the off-spring sex ratio (female/total) calculated. To obtain the percentage egg hatch, the number of eggs that hatched on each host was recorded. Adult dry mass was measured using the method of Nicol \& Mackauer (1999).

\section{Enzyme extraction}

Enzymes were extracted using Bandani et al.'s (2009) method. Briefly, the midguts of fourth instar larvae in a $10 \mathrm{mMNaCl}$ solution were carefully dissected under a stereomicroscope (Stemi SV6 ZEISS, Germany). Midguts (200 midguts $/ \mathrm{ml}$ ) were separated and homogenized in a pre-cooled homogenizer (Teflon pestle). The homogenates from preparations were transferred to $1.5 \mathrm{ml}$ centrifuge tubes and centrifuged at $15,000 \mathrm{~g}$ for $15 \mathrm{~min}$ at $4^{\circ} \mathrm{C}$. The supernatants were pooled and stored at $-20^{\circ} \mathrm{C}$ and used as an enzyme source in subsequent analysis.

\section{$\alpha$-Amylase activity}

$\alpha$-Amylase (protein concentration of $2.0 \mathrm{mg} / \mathrm{ml}$ ) activity was assayed using the dinitrosalicylic acid (DNS) procedure (Bern- feld, 1955) and 1\% soluble starch solution as the substrate as described by Bandani et al. (2009). Briefly, $10 \mu 1$ of the enzyme solution, $20 \mu \mathrm{l}$ of the substrate solution and $70 \mu \mathrm{l}$ of phosphate buffer $\mathrm{pH} 7.0$ were mixed and incubated at $35^{\circ} \mathrm{C}$ for $30 \mathrm{~min}$ after which DNS was added to stop the reaction. The absorbance was read at $540 \mathrm{~nm}$. A blank without substrate but with $\alpha$-amylase extract and a control containing no $\alpha$-amylase extract with substrate were run simultaneously with the reaction mixture. All assays were performed in triplicates and with three replications.

\section{General protease activity}

A general proteolysis assay was done using a slightly modified version of the methods of Saadati \& Bandani (2011) and Gatehouse et al. (1999). Briefly, $10 \mu \mathrm{l}$ of enzyme extract and $50 \mu \mathrm{l}$ of substrate solution (Azocasein 2\%) were mixed with $40 \mu \mathrm{l}$ of 20 $\mathrm{m} \mathrm{M}$ phosphate buffer at $\mathrm{pH} 7.0$. After 60 min incubation $100 \mu \mathrm{l}$ of $30 \%$ trichloroacetic acid (30\% TCA) was added to the reaction mixture, which was then kept at $4^{\circ} \mathrm{C}$ for 30 min and then centrifuged at $15000 \mathrm{~g}$ for $15 \mathrm{~min}$ to precipitate the substrate that was not hydrolyzed. Finally, $100 \mu 11 \mathrm{M} \mathrm{NaOH}$ was added to $100 \mu \mathrm{l}$ of the assay mixture and absorbance measured at $405 \mathrm{~nm}$.

\section{Electrophoresis}

Electrophoretic detection of proteolytic enzymes was done using the procedures described by Laemmli (1970) and Dastranj et al. (2013). PAGE for proteolytic activity was first separated on a $10 \%(\mathrm{~W} / \mathrm{V})$ gel co-polymerized with $0.1 \%$ gelatin and stacked on a $4 \%$ gel with $0.05 \%$ SDS. Electrophoresis was conducted at $4{ }^{\circ} \mathrm{C}$ until the leading dye reached the bottom of the gel. Then, the gel was rinsed with distilled water and washed with $2.5 \%(\mathrm{~V} / \mathrm{V})$ Triton X-100 for 60 min followed by incubation in phosphate buffer $(\mathrm{pH} 7.0$ ) for about $6 \mathrm{~h}$. Finally, the gel was stained as described by Dastranj et al. (2013).

Amylolytic activity in the gel was detected using the procedures described by Mehrabadi et al. (2012). Briefly, PAGE was performed by separating in $8 \%(\mathrm{~W} / \mathrm{V})$ gel and stacked in $4 \%$ gel with $0.05 \%$ SDS. Electrophoresis was run until the blue dye reached the bottom of the gel, after which the gel was removed and rinsed with distilled water and left in a solution of $1 \%(\mathrm{~V} / \mathrm{V})$ Triton X-100 for 15 min. The gel was then taken and put in a solution of a phosphate buffer $(\mathrm{pH} 7)$ containing $1 \%$ starch solution, $2 \mathrm{mM} \mathrm{CaCl} 2$ and $10 \mathrm{mMNaCl}$ for $1.5 \mathrm{~h}$. Finally, the gel was treated with a solution of $1.3 \% \mathrm{I} 2$ and $3 \% \mathrm{KI}$ to stop the reaction and stain the un-reacted starch background. Zones of $\alpha$-amylase activities appeared as light bands against a dark background.

\section{Protein determination}

Protein concentration was measured using Bradford (1976) method with bovine serum albumin as a standard.

\section{Statistical analysis}

Data were compared using the one-way analysis of variance (ANOVA) in SAS 9.1 (SAS Institute, Cary, NC, U.S.A.) followed by a Duncan multiple range test, with significant differences at $\mathrm{P}<0.05$.

TABLE 1. Developmental times (D.T.) (days) of the different stages and total developmental time of $H$. hebetor reared on five different species of lepidopteran hosts.

\begin{tabular}{|c|c|c|c|c|}
\hline HOST & Embryonic D.T. & Larva D.T. & Pupa D.T. & Total D.T. (adult emergence) \\
\hline Plodia interpunctella & $1.89 \pm 0.007^{\mathrm{c}}$ & $5.25 \pm 0.079^{\mathrm{b}}$ & $5.60 \pm 0.040^{\mathrm{e}}$ & $12.76 \pm 0.112^{\mathrm{c}}$ \\
\hline Ephestia kuehniella & $2.35 \pm 0.031^{\mathrm{b}}$ & $5.55 \pm 0.069^{\mathrm{b}}$ & $6.02 \pm 0.015^{\mathrm{d}}$ & $13.92 \pm 0.09^{\mathrm{d}}$ \\
\hline Ectomyelois ceratoniae & $2.24 \pm 0.047^{b}$ & $5.63 \pm 0.059^{b}$ & $6.59 \pm 0.015^{\mathrm{c}}$ & $14.46 \pm 0.039^{\mathrm{e}}$ \\
\hline Helicoverpa armigera & $2.71 \pm 0.031^{\mathrm{a}}$ & $5.68 \pm 0.041^{b}$ & $7.36 \pm 0.063^{b}$ & $15.73 \pm 0.041^{\mathrm{b}}$ \\
\hline Malacosoma disstria & $2.73 \pm 0.047^{\mathrm{a}}$ & $6.28 \pm 0.039^{a}$ & $7.68 \pm 0.015^{\mathrm{a}}$ & $16.70 \pm 0.07^{\mathrm{a}}$ \\
\hline
\end{tabular}

Means indicated by different letters are significantly different (Duncan, $\mathrm{P}<0.05$ ). 


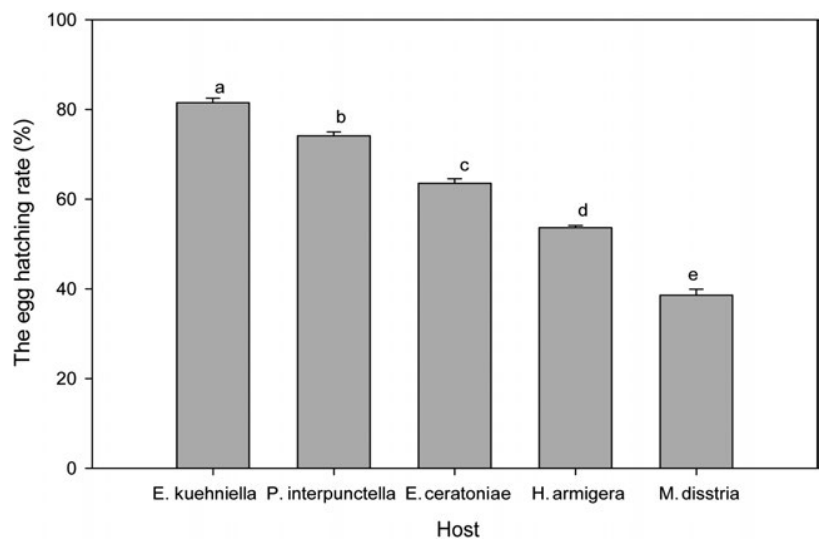

Fig. 1. Percentage egg hatch of $H$. hebetor reared on five different species of lepidopteran hosts. Means indicated by different letters are significantly different (Duncan, $\mathrm{P}<0.05$ ).

\section{RESULTS}

\section{Developmental time}

The duration of the embryonic development of $H$. hebetor depended on the host on which the parent developed (Table 1).

The shortest embryonic period was recorded for the eggs that were laid by parasitoids that developed on $P$. interpunctella and the longest for those that developed on $M$. disstria. The statistical analysis of our findings placed the duration of the embryonic period of $H$. hebetor into one of three groups. The first group included those with the longest embryonic periods, i.e., eggs laid by the parasitoids reared on $H$. armigera and $M$. disstria. The second group those with an intermediate embryonic period, i.e., eggs laid by the parasitoids reared on E. kuehniella and E. ceratoniae. Finally, the third group included the eggs with the shortest embryonic period, i.e., eggs laid by the parasitoid reared on $P$. interpunctella $(\mathrm{F}=73.57, \mathrm{df}=4, \mathrm{P}<0.001)$ (Table 1).

Larval period of the parasitoid on the five hosts differed significantly, with this longest period recorded for those that developed on $M$. disstria (6.28 days) and shortest for those that developed on P. interpunctella (5.25 days). Larval developmental times on E. kuehniella, E. ceratoniae and $H$. armigera, were 5.55, 5.63 and 5.68 days, respectively $(\mathrm{F}=26.25, \mathrm{df}=4, \mathrm{p}<0.0001)$ (Table 1$)$.

The pupal periods of the parasitoids reared on the different lepidopteran hosts also differed significantly, with

TABLE 2. The off-spring sex ratio of $H$. hebetor reared on different species of lepidopteran hosts.

\begin{tabular}{lc}
\hline Host & Off-spring sex ratio $^{1}$ \\
\hline Plodia interpunctella & $0.42 \pm 0.66^{\mathrm{a}}$ \\
Ephestia kuehniella & $0.62 \pm 0.89^{\mathrm{b}}$ \\
Ectomyelois ceratoniae & $0.51 \pm 0.59^{\mathrm{c}}$ \\
Helicoverpa armigera & $0.39 \pm 0.70^{\mathrm{d}}$ \\
Malacosoma disstria & $0.26 \pm 0.55^{\mathrm{e}}$ \\
\hline
\end{tabular}

${ }^{1}$ The sex ratio [female/(male + female)] of $H$. hebetor off-spring. Means indicated by different letters are significantly different (Duncan, $\mathrm{P}<0.05$ ).

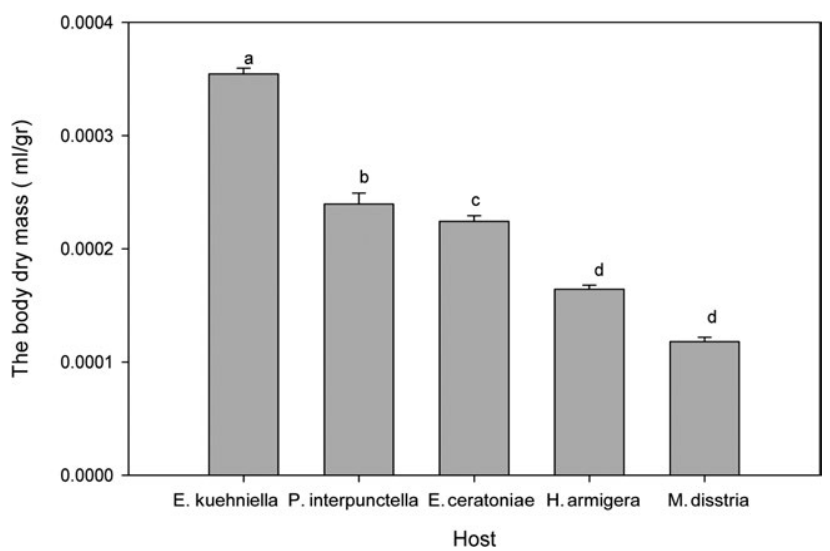

Fig. 2. Adult dry mass of $H$. hebetor reared on five different species of lepidopteran hosts. Means indicated by different letters are significantly different (Duncan, $\mathrm{P}<0.05$ ).

the shortest period recorded for those reared on $P$. interpunctella (5.6 days) and the longest for those reared on $M$. disstria (7.68 days). Pupal developmental times on E. kuehniella, E. ceratoniae and H. armigera were 6.02, 6.56 and 7.33 days, respectively $(\mathrm{F}=777.37, \mathrm{df}=4, \mathrm{p}<0.0001)$.

Total developmental times from egg to adult of this hymenopterous parasitoid reared on P. interpunctella, E. kuehniella, E. ceratoniea, H. armigera and M. disteria were $12.76,13.92,14.46,15.73$ and 16.7 days, respectively, and differed significantly on the different hosts $(\mathrm{F}=406.33$, df $=4, \mathrm{p}<0.0001)$.

\section{Percentage egg hatch}

The percentage egg hatch recorded for the parasitoids reared on the five different hosts differed significantly $(\mathrm{F}=$ $450.815, \mathrm{df}=4, \mathrm{P}<0.001)$. The percentage egg hatch was highest for the parasitoids reared on E. kuehniella $(81.47 \%)$ and lowest for those reared on $M$. disstria (38.57\%). The percentage egg hatch was $74.1,63.52$ and $53.63 \%$, respectively for those reared on $P$. interpunctella, E. ceratonia and $H$. armigera (Fig. 1).

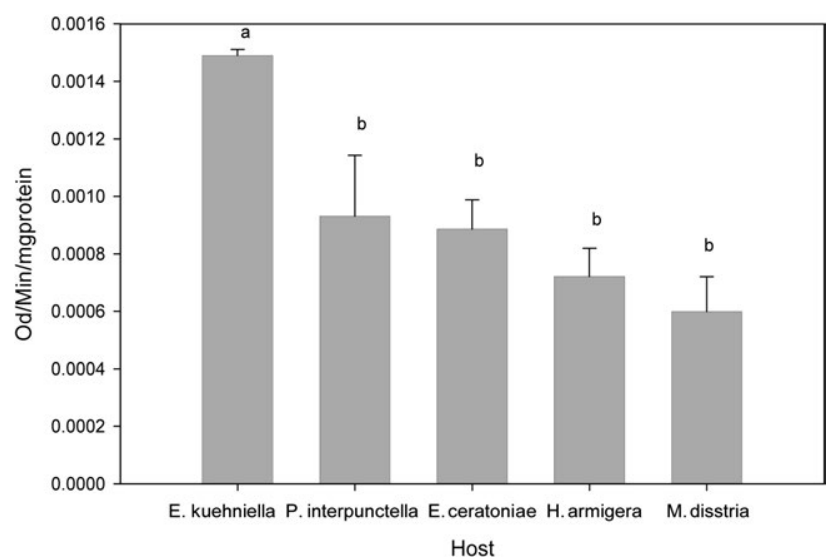

Fig. 3. Protease activity recorded in midgut extracts of larvae of $H$. hebetor reared on five different species of lepidopteran hosts. Each column represents the average of three independent measurements. Means indicated by different letters are significantly different (Duncan, $\mathrm{P}<0.05$ ). 


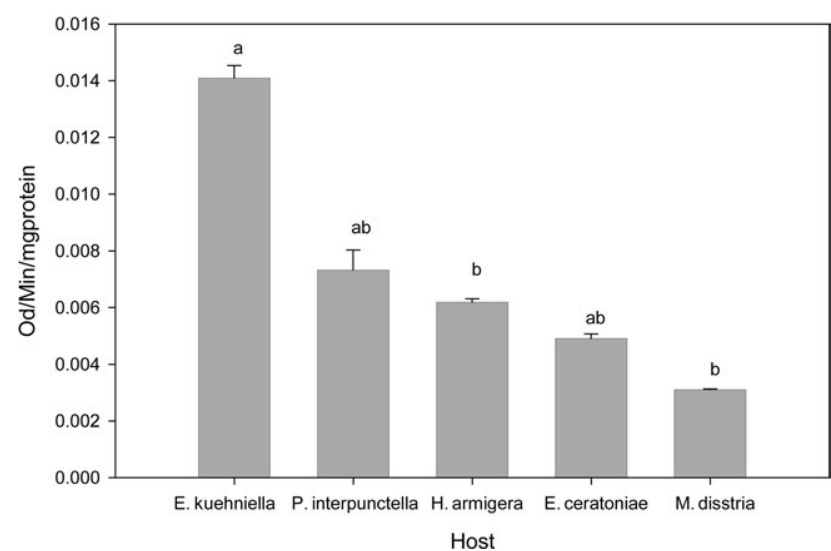

Fig. 4. Amylase activity recorded in midgut extracts of larvae of $H$. hebetor reared on five different species of lepidopteran hosts. Each column represents the average of three independent measurements. Means indicated by different letters are significantly different (Duncan, $\mathrm{P}<0.05$ ).

\section{Sex ratio}

The off-spring sex ratio (female/total) of $H$. hebetor reared on the different hosts differed significantly. The sex ratio was greatest for those reared on E. kuehniella (0.62) and lowest for those reared on M. disstria (26.1) (Table 2). The sex ratio was $0.42,0.51$ and 0.39 for those reared on $P$. interpunctella, E. ceratoniae and $H$. armigera, respectively, and differed significantly on the different hosts $(\mathrm{F}=$ 278.706, df $=4, \mathrm{P}<0.001$ ) (Table 2).

\section{Adult dry mass}

There were significant differences in the adult dry mass of the parasitoid reared on the different insect hosts $(\mathrm{F}=$ 217.47, df $=4, \mathrm{P}<0.0001$ ) (Fig. 2). The greatest dry mass was recorded when they were reared on E. kuehniella and the lowest when reared on $M$. disstria. There were no significant differences in parasitoid dry mass when they were reared on H. armigera and E. ceratoniea (Fig. 2).

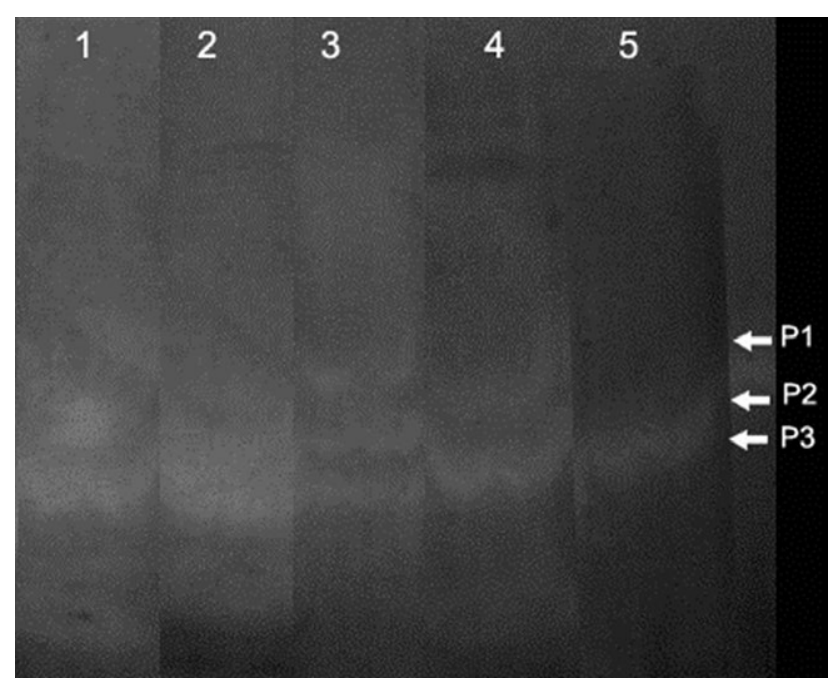

Fig. 5. Proteolytic activity recorded electrophoretically in midgut extracts of larvae of $H$. hebetor using $1 \%$ gelatin as the substrate. Numbers are as follow: 1 - Ectomyelois ceratoniae, 2 - Ephestia kuehniella, 3 - Malacosoma disstria, 4 - Plodia interpunctella, 5 - Helicoverpa armigera.

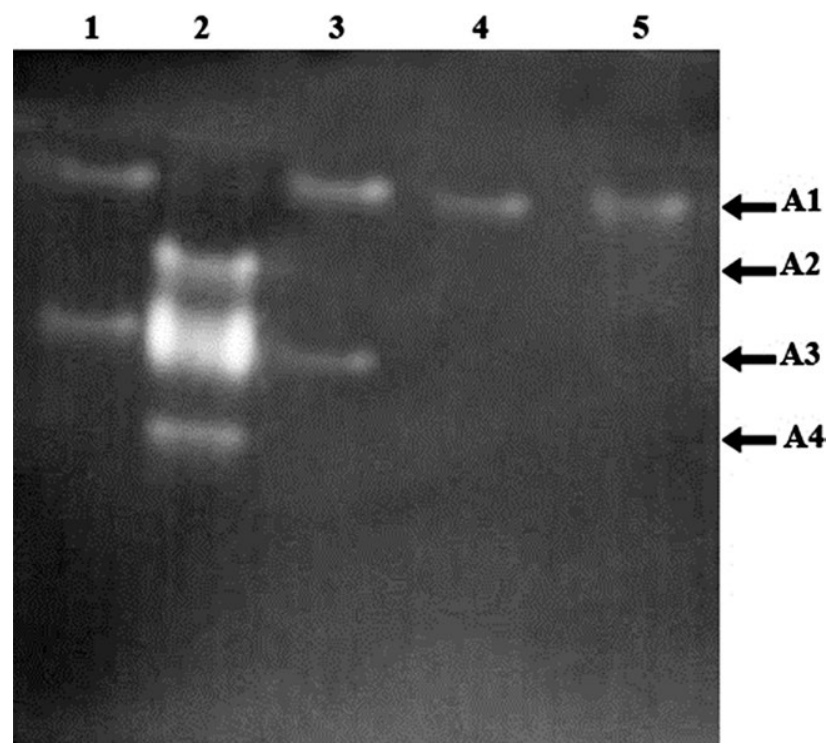

Fig. 6. Amylolytic zymogram of midgut extracts of larvae of $H$. hebetor reared on five different species of lepidopteran hosts using $1 \%$ starch as the substrate. Numbers are as follow: $1-E c$ tomyelois ceratoniae, 2 - Ephestia kuehniella, 3 - Malacosoma disstria, 4 - Plodia interpunctella, 5 -Helicoverpa armigera.

\section{Protease activity}

The level of general protease activity recorded in the midgut of the parasitoid larvae was highest when they were reared on E. kuehniella (Fig. 3), being almost two times that recorded for larvae reared on the other hosts. The lowest protease activity was recorded in the midguts of larvae reared on $M$. disstria. The order of the protease activity recorded in the midguts of the larvae reared on the different hosts was E. kuehniella $>H$. armigera $>$ E. ceratoniae $>P$. interpunctella $>$ M. disstria (Fig. 3).

In the gel assay (Fig. 5) three protease bands (P1, P2, and P3) were recorded when the parasitoid was reared on $E$. kuehniella and $M$. disstria, only one (P3) band when it was reared on $H$. armigera and two bands (P2 and P3) when reared on E. ceratoniae and $P$. interpunctella.

\section{Amylase avtivity}

The level of amylase activity recorded in the midguts of the parasitoid larvae was highest when they were reared on E. kuehniella, followed by $P$. interpunctella, $H$. armigera, E. ceratoniae and M. disstria (Fig. 4). The lowest $\alpha$-amylase activity was recorded in the midguts of larvae reared on $M$. disstria. Interestingly, the gel assay revealed three clear amylase bands (A2, A3 and A4) for the parasitoid larvae reared on E. kuehniella and fewer bands for those reared on the other hosts (Fig. 6). Only two faint amylase bands (A1 and A3) were recorded for the parasitoid larvae reared on $E$. ceratoniae and $M$. disstria, and one faint band (A1) for those reared on P. interpunctella and $H$. armigera (Fig. 6).

\section{DISCUSSION}

The current study revealed that although $H$. hebetor can parasitize several different lepidopteran hosts, its development time, off-spring sex ratio, percentage egg hatch and 
adult dry mass significantly depends on the host $(\mathrm{P}<0.05)$. For example, $P$. interpunctella and E. kuehniella were the best hosts in terms of all the parameters evaluated. However, in terms of developmental time and off-spring sex ratio P. interpunctella was a better host than E. kuehniella. For example, total developmental time of the parasitoid reared on P. interpunctella was 12.76 days and on E. kuehniella 13.92 days. The off-spring sex ratio recorded for the parasitoids reared on the $P$. interpunctella and E. kuehniella were 0.42 and 0.62 , respectively. However, in terms of percentage egg hatch and adult dry mass, E. kuehniella was a much better host than $P$. interpunctella. Both of these hosts (P. interpunctella and E. kuehniella) are important stored product pests (Heimpel et al., 1997; Darwish et al., 2003). The performance of this parasitoid on field crop pests such as $M$. disstria, a serious pest of deciduous hardwood trees (Batzer \& Morris, 1978) and H. armigera, a polyphagous and cosmopolitan insect pest of various plant species, including cotton, maize and tomato (Sharma et al., 2004; Srinivas et al., 2004) was poor i.e. it took longer to complete its development on these two hosts. According to Dabhi et al. (2011) the performance of Habrobracon hebetor on stored product insects, like Corcyra cephalonica, a pest of stored products such as cereals, cereal products, oilseed, pulses, dried fruit, nuts and spices, and $S$. cerealella, a serious pest of cereal kernels, was much better than on $H$. armigera, S. litura and E. vittella.

Interestingly, the level of activity of the digestive enzymes $\alpha$-amylase and general proteases in the larvae of the parasitoid was highest in those reared on the two stored product pests ( $P$. interpunctella and E. kuehniella). For example, in terms of $\alpha$-amylase activity, three clear amylase bands were recorded for the larvae of the parasitoid reared on E. kuehniella, indicating that this host provides better nutrition than the other hosts, which induced a higher digestive enzyme activity.

The activity of enzymes in the guts of larvae reared on other hosts, such as $M$. disstria and $H$. armigera was lower (qualitative measure) and there were fewer isoenzymes (quantitative measure). One explanation of this is that those parasitoid hosts that feed on a diet rich in secondary metabolites, such as tannins and terpenes, which adversely affect the growth of the host are likely to also affect the growth and development of the parasitoid and the activity of its digestive enzymes. It is likely that some compounds in the host inhibited the activity of the digestive enzymes of the parasitoid (Boigegrain et al., 1992) because when reared on these two hosts the activities of both of their digestive enzymes (amylase and proteases) were less and there were fewer isoenzymes in the extracts. The lowest amylase and protease activity were recorded in the guts of the parasitoid larvae reared on $M$. disstria and the highest in the gut of those reared on E. kuehniella. The same pattern was recorded for percentage egg hatch, off-spring sex ratio and adult dry mass i.e. in terms of these parameters the performance was much better when the parasitoid was reared on stored product insects, such as E. kuehniella and $P$. interpunctella, which accords with findings of Jhansi \&
Babu (2003) and Dabhi et al. (2011). B. hebetor reared on fifth instar larvae of Anagasta kuehniella (Zeller) (Lepidoptera: Pyralidae) (natural diet) and in vitro (artificial diet) did better on the natural diet in terms of the time it took them to complete their larval and pupal development, which indicates that the artificial diet was less suitable than the natural diet. A similar situation was recorded in this study as the field crop insects proved to be less suitable hosts than the larvae of stored product pests.

Based on these findings it is concluded that stored product insect pests, such as P. interpunctella and E. kuehniella, are more suitable hosts than field crop pests, such as $M$. disstria and $H$. armigera, for the parasitoid $H$. hebetor since it performs better on stored product insects. In addition, the parasitoid's digestive enzymes function better qualitatively and quantitatively indicating that stored product insects provide more suitable nutrition for the parasitoid. Thus, it is concluded that of those tested store product insects are the most suitable for the viability of this parasitoid.

ACKNOWLEDGEMENTS. This work was funded by a grant from the University of Tehran.

\section{REFERENCES}

Akinkurolere R.O., Boyer S., Chen H. \& Zhang H. 2009: Parasitism and host-location preference in Habrobracon hebetor (Hymenoptera: Braconidae): Role of refuge, choice, and host instar. - J. Econ. Entomol. 102: 610-615.

BAKER J.E. \& FABRICK J.A. 2000: Host hemolymph proteins and protein digestion in larval Habrobracon hebetor (Hymenoptera: Braconidae). - Insect Biochem. Mol. Biol. 30: 937-946.

Bandani A.R., Kazzazi M. \& Mehrabadi M. 2009: Purification and characterization of midgut $\alpha$-amylases of Eurygaster integriceps. - Entomol. Sci. 12: 25-32.

Batzer H.O. \& Morris R.C. 1978: Forest Tent Caterpillar. U.S. Depart. Agriculture, Forest Service, Forest Insect and Disease Leaflet 9. Available at http://willow.ncfes.umn.edu/fidl.

Bernfeld P. 1955: Amylases, alpha and beta. - Method. Enzymol. 1: 149-158.

Boigegrain R.A., Mattras H., Brehelin M., Paroutaud P. \& Coletti-Previero M.A. 1992: Insect immunity: Two proteinase inhibitors from hemolymph of Locusta migratoria. - Biochem. Biophys. Res. Commun. 189: 790-793.

BRADFORD M. 1976: A rapid and sensitive method for quantitation of microgram quantities of protein utilizing the principle of protein-dye binding. - Anal. Biochem. 72: 248-254.

Brower J.H., Smith L., Vail R.C. \& Flinn P.W. 1996: Biology control. In Subramanyam B. \& Hagstrum D.W. (eds): Integrated Management of Insects in Stored Products. Marcel Dekker, New York, pp. 223-286.

Dabhi M.R., Korat D.M. \& Vaishav P.R. 2011: Comparative biology of Bracon hebetor Say on seven lepidopteran hosts. Karnataka J. Agric. Sci. 24: 549-550.

Darwish E., El-Shazly M. \& El-Sherif H. 2003: The choice of probing sites by Bracon hebetor (Say) (Hymenoptera: Braconidae) foraging for Ephestia kuehniella Zeller (Lepidoptera: Pyralidae). - J. Stored Prod. Res. 39: 265-276.

Dastranj M., Bandani A.R. \& Mehrabadi M. 2013: Age-specific digestion Tenebrio molitor (Coleoptera: Tenebrionidae) and inhibition of proteolytic and amylolytic activity by plant proteinaceous seed extracts. - J. Asia Pac. Entomol. 16: 309-315.

Gatehouse A.M.R., Norton E., Davison G.M., BabBe S.M., NewELl C.A. \& Gatehouse J.A. 1999: Digestive proteolytic activity 
in larvae of tomato moth, Lacanobia oleracea, effects of plant protease inhibitors in vitro and in vivo. - J. Insect Physiol. 45: 545-558.

Ghimire M.N. \& Phillips T.W. 2010: Suitability of different lepidopteran host species for development of Bracon hebetor (Hymenoptera: Braconidae). — J. Environ. Entomol. 39: 449-458.

Grieshop M.J., Flinn P.W. \& Nechols J.R. 2006: Biological control of indian meal moth (Lepidoptera: Pyralidae) on finished stored production using egg and larval parasitoids. - J. Econ. Entomol. 99: 1080-1084.

Heimpel G.E., Antolin M.F., Franqui R.A. \& Strand M.R. 1997: Reproductive isolation and genetic variation between two "strains" of Bracon hebetor (Hymenoptera: Braconidae). Biol. Contr. 9: 149-156.

Imam M., Uwais A., Namat U., Akbar A. \& Ahmat T. 2007: Influence of Habrobracon hebetor on $H$. armigera armigera in southern Xinjiang. - J. Nat. Enem. Insects 29: 12-15.

JHANSI K. \& BABU P.C.S. 2003: Comparative biology of Bracon hebetor Say in two host insects. - J. Appl. Zool. Res. 14: $165-168$.

Keever D.W, Mullen M.A., Press J.W. \& Arbogast R.T. 1986: Augmentation of natural enemies for suppressing two major insect pests in stored farmer's stock peanuts. - J. Environ. Entomol. 15: 767-770.

Kishani-Farahani H., Goldansaz S.H. \& Sabahi Q. 2012: A survey on the overwintering larval parasitoids of Ectomyelois ceratoniae in three regions in Iran. - Crop. Prot. 36: 52-57.

Kryukova N.A., Dubovskiy I.M., Chertkova E.A., Vorontsova Y.L., Slepneva I.A. \& Glupov V.V. 2011: The effect of Habrobracon hebetor venom on the activity of the prophenoloxidase system, the generation of reactive oxygen species and encapsulation in the haemolymph of Galleria mellonella larvae. - J. Insect. Physiol. 57: 796-800.

LAEMMLI U.K. 1970: Cleavage of structural proteins during the assembly of bacteriophage T4. - Nature 227: 680-685.
Magro S.R., Dias A.B., Terra W.R. \& Parra J.R.P. 2006: Biological, nutritional, and histochemical basis for improving an artificial diet for Bracon hebetor Say (Hymenoptera: Braconidae). - Neotrop. Entomol. 35: 215-222.

Mehrabadi M., Bandani A.R., Mehrabadi R. \& Alizadeh H. 2012: Inhibitory activity of proteinaceous $\alpha$-amylase inhibitors from Triticale seeds against Eurygaster integriceps salivary $\alpha$-amylases: Interaction of the inhibitors and the insect digestive enzymes. - Pestic. Biochem. Physiol. 102: 220-228.

Nicol C.M.Y. \& Mackauer M. 1999: The scaling of body size and mass in a host-parasitoid association: influence of host species and stage. - Entomol. Exp. Appl. 90: 83-92.

Press J.W., Cline L.D. \& Flaherty B.R. 1982: A comparison of two parasitoids, Bracon hebetor (Hymenoptera: Braconidae) and Venturia canescens (Hymenoptera: Ichneumonidae), and a predator Xylocoris flavipes (Hemiptera: Anthocoridae) in suppressing residual populations of the almond moth, E. cautella (Lepidoptera: Pyralidae). - J. Kansas Entomol. Soc. 55: 125-128.

SAADATI F. \& BANDANI A.R. 2011: Effects of serine protease inhibitors on growth and development and digestive serine proteinases of the Sunn pest, Eurygaster integriceps. - J. Insect Sci. 2: 72. Available online: insectscience.org/2.72.

Sharma H.C., Pampapathy G. \& Kumar R. 2004: Standardization of cage techniques to screen chick pea for resistance to $H$. armigera (Hübner) in green house and field conditions. $-J$. Econ. Entomol. 98: 210-216.

Srinivas R., Udiken S.S,. Jayalakshmi S.K. \& SReeramulu K. 2004: Identification of factors responsible for insecticide resistancen in H. armigera (Hübner). - Comp. Biochem. Physiol. 137: 261-269.

Uwais A., Xu J.J., Yang X.R., He J.T., Guo W.C., Xu Y.-Q. \& WeI Y.-Q. 2006: Preliminary test of controlling H. armigera armigera and Ostrinia furnacalis with Habrobracon hebetor in fields. - Chin. Biol. Contr. 22: 155-157.

Received February 10, 2014; revised and accepted May 26, 2014 Prepublished online August 19, 2014 